\title{
Review: The Upper Amazon Basin
}

Source: The Geographical Journal, Vol. 45, No. 3 (Mar., 1915), p. 244

Published by: geographicalj

Stable URL: http://www.jstor.org/stable/1779802

Accessed: 26-04-2016 21:51 UTC

Your use of the JSTOR archive indicates your acceptance of the Terms \& Conditions of Use, available at

http://about.jstor.org/terms

JSTOR is a not-for-profit service that helps scholars, researchers, and students discover, use, and build upon a wide range of content in a trusted digital archive. We use information technology and tools to increase productivity and facilitate new forms of scholarship. For more information about JSTOR, please contact support@jstor.org.

The Royal Geographical Society (with the Institute of British Geographers), Wiley are collaborating with JSTOR to digitize, preserve and extend access to The Geographical Journal 
manufacturers of the country. Moreover, since railways have been opæned and brigandage abolished, adjacent countries such as Khorasan, northern Afghanistan, and Kashgaria have opened up a thriving trade with Turkestan, while Russian administration has given the land peace, security, and if not ideal government, at all events one vastly superior to that which preceded it. One conspicuous defect, in M. Woeikof's opinion, is that the upper government officials have a very imperfect acquaintance with the native languages, while their subordinates have no regular defined or permanent employment, with concomitant advantages as regards pay and annual leave, such as are enjoyed in the British and Dutch East Indies.

\section{AMERICA,}

The Upper amazon Basin.

'The Upper Reaches of the Amazon.' By Joseph F. Woodroofe. London : Methuen \& Co. 1914. Pp. xvi., 304. Map and Illustrations. 10s. 6d. net.

This book is the record by a young Englishman of between seven and eight years' residence in the upper Amazon basin, during which period he experienced many vicissitudes, at one time working his way up to the command of a prosperous business, but for the most part serving as an employe in the rubber-collecting industry. He ranged from Manaos to beyond Iquitos in the one direction, and to the Madeira-Mamore railway in the other. In the course of his varied employment he became associated with the notorious company exploiting the rubber resources of the Putumayo. His participation in the business after he became aware of its character he excuses by explaining that he himself was "a victim of peonage," being accounted heavily in debt to his patrons.

Having this basis of experience, he has written this book with a twofold object-to warn other young Englishmen of the dangers of employment in the outlying parts of the Amazon basin, and to expose the evils attendant on the collection of rubber, not only in the Putumayo, but, to a greater or less extent, throughout the area which came within the range of the author's observation. About two-thirds of the book is occupied with the personal narrative; the rest is devoted to a generalized account of the conditions under which the rubber industry is carried on, natural history notes, and a few hints for travellers. Particularly instructive is a detailed description and estimate of the cost of starting and working a "seringal," or rubber estate, in the Amazonian forests. From this it appears that the workers are not the only sufferers from a vicious system, under which the masters themselves are often in a sorry position.

Apart from its main theme, the book is interesting for its ingenuous details of life and travel in the upper Amazon basin. Without literary graces, and lacking the scientific value of the record of a trained observer, it presents in popular form a good deal of information, and should do much to spread knowledge of a region which, in the ordinary way, comes little into the light, but which has already attained economic importance and has potentialities of vast development.

\section{POLAR REGIONS.}

Antarctic Domestic Economy.

'Antarctic Adventure. Scott's Northern Party.' By Raymond E. Priestley. London : T. Fisher Unwin. 1914. Map and 150 Illustrations. 158. net.

Mr. Priestley's detailed account of the life of the members of Scott's Northern Party, under the command of Lieut. Campbell, presents many features of great 